\title{
A tudásalapú fejlődés lehetőségei az EU lemaradó régióiban
}

\author{
Pólónyi-Andor Krisztina \\ Pécsi Tudományegyetem
}

\begin{abstract}
A TANULMÁNY CÉLJA
Napjainkban a tudásalapú fejlődés mint cél egyre hangsúlyosabb az Európai Unión belül. Nem csak a fejlett, de a lemaradó régiók számára is fontos az innovativitás és ezáltal a versenyképesség növelése. A gyakorlati tapasztalatok azonban azt mutatják, hogy a kevésbé fejlett régióknak számos kihívással kell szembenézniük ezen a területen. A tanulmány célja, hogy bemutassa azokat a tényezőket, melyek hátráltatják, illetve azokat a javaslatokat, melyek segíthetik a lemaradó régiókat a tudásalapú felzárkózás elérésében.
\end{abstract}

\section{ALKALMAZOTT MÓDSZERTAN}

A tanulmányban alkalmazott módszertan a szakirodalmi feldolgozás. A szakirodalom alapján összegyủjtésre kerültek azok a tényezők, melyek gátolják a lemaradó régiókban a tudásalapú fejlődést, továbbá azok a fejlesztési javaslatok, melyek kifejezetten ezeket a régiókat támogatják.

\section{LEGFONTOSABB EREDMÉNYEK}

A szakirodalom alapján jól körvonalazódnak azok a tényezők, melyek akadályt jelentenek a lemaradó régiók számára a tudásalapú felzárkózás során. Ilyen például az elégtelen humán tőke kapacitás, a gyenge vállalati szféra, az elégtelen minőségủ intézményi környezet, a rögzült sémákból való kitörés nehézsége, a $\mathrm{K}+\mathrm{F}$ kiadások alacsony szintủ megtérülése és sok esetben a régiók történelmi múltja. A problémák feloldására számos javaslat született, mint például az abszorpciós kapacitások növelése a külső tudás átvétele érdekében, erős vállalkozói ökoszisztéma kialakítása, az intézményi környezet fejlesztése, a régió sajátosságaihoz illő innovációs politika megválasztása. Emellett az egyetemekről kiinduló pozitív hatások is meghatározók lehetnek, bár törekedni kell arra, hogy az innovációs rendszer minden szereplője megfelelő képességekkel rendelkezzen, és együttmúködjön a régió fejlődése érdekében.

\section{GYAKORLATI JAVASLATOK}

Annak ellenére, hogy jelentős hiányoságokkal rendelkeznek ezen a területen, a lemaradó régióknak is törekedniük kell a tudásalapú fejlődésre. Mivel speciális kihívásokkal néznek szembe, nem elegendő a fejlett régiók gyakorlatait átvenniük, hanem a fejlesztéspolitikájukat a saját kapacitásaikhoz kell igazítaniuk.

Kulcsszavak: lemaradó régiók, tudásalapú fejlődés, regionális politika

Köszönetnyilvánitás: Jelen publikáció az Európai Unió, Magyarország és az Európai Szociális Alap társfinanszírozása által biztosított forrásból az EFOP-3.6.2-16-2017-00017 azonosítójú „Fenntartható, intelligens és befogadó regionális és városi modellek" címủ projekt keretében jött létre.

DOI: 10.15170/MM.2020.54.KSZ.I.03 


\section{BEVEZETÉS INTRODUCTION}

Napjainkban az innovációra építő és tudásalapú fejlődés, mint cél egyre nagyobb hangsúlyt kap. Számos politikai intézkedés törekszik elősegíteni a régiók innovativitásának, és ezáltal versenyképességének növelését. Ez az elv megmutatkozik az Európai Unió kohéziós politikájában is, melyben a 2014-2020-as tervezési periódusra az intelligens szakosodás stratégiája (S3) vált irányadóvá. Az S3 koncepció (Foray et al. 2012, Foray 2019) ugyanis olyan prioritási területek támogatását célozza, melyek többek között nagy innovációs potenciállal rendelkeznek.

A lemaradó régiók azonban jellemzően inkább innováció követők, mintsem vezető innovátorok, ennek megfelelően az innovativitásuk és a tudásbázisuk is alacsonyabb szintü, mint a fejlettebb régióké, a tudásalapú gazdaság kialakításához szükséges feltételek is kevésbé, vagy egyáltalán nem adottak. Így számos nehézséggel néznek szembe az innovációs politikák megvalósítása során, melyek sikeressége gyakran limitált. Miért fontos mégis foglalkozni azzal, hogy a fejletlen, gyenge innovációs rendszerrel rendelkező régiók innovatívabbak legyenek? Kell-e erőltetni ezekben a régiókban a tudásalapú felzárkózást? Rodríguez-Pose és Fitjar (2013) felhívják a figyelmet arra, hogy a fejletlen régiók kétféle utat választhatnak. Az egyik lehetőség szerint nem törekednek a növekedésre, az innovációs képességeik erősítésére. Ekkor azonban egyre növekvő lesz a lemaradásuk, mivel nem várható, hogy az élen járó régiókból 'lecsorog' hozzájuk a fejlődés. A másik lehetőség, hogy a politika létrehoz, és véghezvisz egy fejlesztési stratégiát, amely illeszkedik a térség adottságaihoz, és a lemaradás csökkentését célozza. A szerzők szerint a régiók felzárkózása ebben az esetben sem biztos, hogy megvalósul, az esélye azonban így megvan (RodríguezPose \& Fitjar 2013). Magyarország jelentős része az EU lemaradó régiói közé tartozik, az ország innovációs teljesítménye az utóbbi években több mutatószám alapján is inkább romlott vagy stagnált növekedés helyett (Polónyi 2018). Így tehát hazánkban különösen fontos foglalkozni azzal, hogy a lemaradó régiókban melyek a fejlödés legjellemzőbb akadályozó tényezői, továbbá milyen intézkedések segíthetik a felzárkózást. Jelen tanulmány ehhez kíván támogatást nyújtani.

Mielőtt azonban rátérünk a tudásalapú fejlődés lehetőségeinek vizsgálatára, nézzük meg, hogy mit is jelent a 'lemaradó régió' kifejezés. Az Európai Bizottság a lemaradó régiók két csoport- ját különbözteti meg: 'alacsony növekedésủ régiók' és 'alacsony jövedelmű régiók'. Előbbibe azok a kevésbé fejlett, illetve átmeneti régiók tartoznak, melyek 2000 és 2013 között nem konvergáltak az EU átlaghoz, továbbá olyan országhoz tartoznak, mely 2013-ban az EU átlag alatt teljesített GDP/ fő tekintetében. Alacsony jövedelmü régiónak pedig azokat a régiókat nevezzük, melyek GDP/ fó értéke 2013-ban nem érte el az EU átlag 50\%-át (European Commission 2017). Emellett az Európai Bizottság azokat a régiókat tekinti felzárkózó régióknak, melyek fejlődési szintje szignifikánsan alacsonyabb, mint az EU átlag. A felzárkózó régiókra adott pontosabb meghatározás megfeleltethető a lemaradó régiók definíciójával (European Commission 2020). Megfigyelhetö, hogy a fenti meghatározás elsősorban a 2013-as teljesítmény alapján osztályozza a régiókat. A gazdasági szakirodalomban a tanulmányok jelentős része nem definiálja, hogy mit ért lemaradó vagy kevésbé fejlett régió alatt, ami nehezíti a szakirodalom feldolgozását. Továbbá Eder (2018) felhívja a figyelmet, hogy a szerzők gyakran használják a 'periférikus', 'lemaradó', 'hátrányos helyzetü' kifejezéseket szinonimaként, ezért az elemzés során fontos ezeket is figyelembe venni.

\section{A LEMARADÓ RÉGIÓK KIHÍVÁ- SAI A TUDÁSALAPÚ FEJLŐDÉS TERÉN \\ THE CHALLENGES OF THE LAGGING REGIONS IN THE FIELD OF KNOWELDGE-BASED DEVELOPMENT}

A lemaradó régiók számos kihívással néznek szembe a tudásalapú felzárkózás terén. Elöször azonban érdemes kitérni az innovativitás mérésében rejlő problémákra, miszerint a fejletlen régiók felzárkózásához szükséges innovációkat és a technolóigai élvonalon mozgó innovációs tevékenységeket nem lehet ugyanazzal a módszerrel mérni (Eder 2018, Kravtsova \& Radosevic 2012). Például az európai innovációs pontrendszer (EIS) az innovációs élvonalbeli tevékenységeket veszi alapul, így nem alkalmas benchmarknak az élvonal mögötti régiók számára. Emellett megkülönböztethető az innovátorok lassú és gyors típusa is (Shearmur 2015). Előbbire jellemző, hogy kevésbé gyakran lép interakcióba más innovációs vagy gazdasági szereplőkkel, illetve jellemzően hosszú idő alatt elavuló információkra épít. Ezzel szemben a gyors innovátorok gyakran interaktálnak más 
szereplőkkel, és többnyire olyan információkat használnak fel, melyek gyorsan elévülnek. Shearmur és Doloreux (2016) a lassú és a gyors innovátorok térbeli eloszlásának vizsgálata során megállapítják, hogy a nagyvárosokban nagyjából azonos arányban találhatók meg a gyors és a lassú innovátorok, míg a nagyvárosoktól távoli, azoktól elszigetelt területeken túlnyomó részt lassú innovátorok vannak jelen. (Shearmur \& Doloreux 2016) Ez is alátámasztja azt a gondolatot, hogy a fejlett és a fejletlenebb térségek innovációs tevékenysége eltérő, így a teljesítményüket nehéz ugyanazzal a módszerrel összehasonlítani.

A lemaradó régiók tudásalapú felzárkózása során meghatározó tényező a régiók történelmi öröksége. Az Európai Unió kevésbé fejlett régióinak jelentős részét képezik azok a térségek, melyekben korábban szocialista rendszer uralkodott. Bár a rendszerváltás már harminc éve megtörtént, ezek a régiók továbbra is rendelkeznek néhány sajátos és meghatározó tulajdonsággal. Karbowski (2017) rávilágít, hogy a szocialista gazdaságokban a $\mathrm{K}+\mathrm{F}$ tevékenységek központi irányítás alatt müködtek, majd a rendszerváltást és a korábbi piacok elvesztését követően a vállalatoknak egy teljesen új kapcsolati hálót kellett kiépíteniük az új partnereik körében, így aztán nem meglepő, hogy a vállalatok közötti bizalom, még nem erősödött meg kellő mértékben. Ahogy Dyker és Radosevic (2000) rámutatnak, a rendszerváltásnak voltak olyan elemei, melyek a tudásgazdaság kialakulását segítették. A privatizáció hozzájárult az országok tudásbázisának növekedéséhez, lehetővé tette ugyanis a vállalati formák, méretek és stratégiák diverz megjelenését, mely elengedhetetlen a tudás létrehozásához és terjedéséhez. Továbbá hatással volt a vállalaton belül kialakuló hálózatok formáira és az állami politika gazdasági fejlődést befolyásoló tevékenységére is. A szerzők azonban rávilágítanak, hogy az alkalmazott liberalizációs politikák (a vállalkozói szabadság megteremtése, a profit lehetőségek szabad kihasználása) elengedhetetlen, de nem elégséges feltételei a tudásalapú gazdaság megteremtésének. Veugelers és Mrak (2009), illetve Veugelers (2011) empirikus elemzései azt mutatják, hogy tudásgazdasági értelemben minden új EU tagállam jelentős lemaradással indult az EU-27-hez képest, mely rést egyik országnak sem sikerült teljesen megszüntetnie. Az elemzések alapján az új EU tagállamok sikeresebbek voltak a gazdasági értelemben vett felzárkózás terén, mint a tudásgazdaság tekintetében vett konvergencia esetében. Előbbiben robusztus felzárkózás figyelhető meg, míg az utóbbiban a konvergencia lassú és nemzetenként meglehetősen eltérő folyamatként jellemezhető. Papava (2018) megállapítja, hogy a posztszocialista országoknak nem sikerült kiépíteniük erôs nemzeti innovációs rendszert, továbbá kialakult egy olyan egyenlötlen helyzet, melyben az új technológiák a nyugat-európai országokban koncentrálódnak, míg a kelet-európai országok jellemzően a régi technológiákat használják.

A tudásalapú fejlődést elősegíteni kívánó politikák elterjedt eszközei a $\mathrm{K}+\mathrm{F}$ ösztönzők. A $\mathrm{K}+\mathrm{F}$ kiadások megtérülését számos szakirodalom vizsgálja, az eredmények azonban meglehetősen változók országonként, cégenként és időben is (Kokko et al. 2015). Rodríguez-Pose és Wilkie (2018) a lemaradó régiókban vizsgálta, hogy milyen strukturális, szociális és gazdasági faktorok hatnak az innovativitásra. Eredményeik alapján az üzleti szektor $\mathrm{K}+\mathrm{F}$ kiadása pozitívan befolyásolja a régiók innovációs aktivitását, azonban a regionális felsőoktatási és az állami szektor $\mathrm{K}+\mathrm{F}$ kiadásának nincs szignifikáns hatása. Rodríguez-Pose és Wilkie (2017) kelet-közép-európai régiók elemzése során arra az eredményre jutott, hogy a vizsgált időszakban a régiók a növekvő $\mathrm{K}+\mathrm{F}$ beruházások által nem tudták növelni az innovációs kapacitásukat, illetve nem voltak képesek jelentős társadalmi-gazdasági fejlődést elérni. Kravtsova és Radosevic (2012) szintén azt állapítják meg, hogy a kelet-európai országok termelékenysége alacsonyabb, mint ami a $\mathrm{K}+\mathrm{F}$ kapacitásukat és a termelési kapacitásukat tekintve várható lenne, ami arra mutat rá, hogy ezek az erőforrások nem hatékonyan járulnak hozzá a termelékenység növekedéséhez.

Felmerül a kérdés, hogy vajon mi áll amögött, hogy az Európai Unió perifériájához tartozó országokban meglehetősen alacsony a $\mathrm{K}+\mathrm{F}$ kiadások megtérülése. Rodríguez-Pose és Wilkie (2017) ennek magyarázatára három meghatározó faktort azonosít. Az egyik az országok elégtelen humán tőke kapacitása. A periférikus térségekben gyakran okoz problémát az, hogy a munkaerőnek relatíve kis aránya rendelkezik felsőfokú képzettséggel, az oktatás minősége alacsony, és jellemző a jó képességü munkaerő kivándorlása fejlettebb gazdaságokba. Mivel a fejletlen régiókban nem áll rendelkezésre a képzett munkaerő szükséges állománya, az innovatív tevékenységek kialakítása és bevonzása, a tudásgazdaság kialakítása nehézségekbe ütközik (Sotarauta \& Kosonen 2004). A lemaradó régiók tudásalapú fejlődésének és a $\mathrm{K}+\mathrm{F}$ kiadások megtérülésének komoly gátat szab az intézményi kapacitások elégtelen minősége is, aminek a fejlesztése kihívások elé állítja a regionális politikát (Rodríguez-Pose \& Wilkie 2017, Radosevic 2018). A következő fontos tényező, mely korlátozza a $\mathrm{K}+\mathrm{F}$ kiadások megtérülését, a gyenge vállalati szféra. 
A lemaradó régiókban jellemző a kis és gyenge gazdasági erővel rendelkező vállalatok többsége, a meghatározó szektorok túlnyomóan tradicionális ágazatok, melyek nem tudásintenzívek, így az innovációs potenciáljuk is gyenge (Rodríguez-Pose \& Wilkie 2017). Karbowski (2017) rámutat, hogy a kelet-közép-európai országok esetében a $\mathrm{K}+\mathrm{F}$ nagy része nem a régión belül zajlik, hanem külföldről importálják, mégpedig a nemzetközi vállalatok által behozott termelési folyamatok során. Továbbá a kelet-közép-európai országokban az innovációs tevékenységek túlnyomóan a bevált minták utánzásán és nem a kreativitáson alapulnak. (Karbowski 2017) Mindemellett kihívást jelent a lemaradó régiók számára a szükös erőforrások és kompetenciák mobilizálása és a rögzült sémák áthidalása, melyek jelentős mértékben hátráltatják a fejlesztési törekvéseket (Sotarauta \& Kosonen 2004).

\section{A LEMARADÓ RÉGIÓK FEJ- LESZTÉSI LEHETŐSÉGEI THE DEVELOPMENT OPPOR- TUNITIES OF THE LAGGING REGIONS}

A lemaradó régiók tudásalapú felzárkózása érdekében számos javaslat született a gazdasági szakirodalomban. Kravtsova és Radosevic (2012) szerint a kelet-európai országokban különbséget kellene tenni a technológia kifejlesztése és felhasználása között. Ezekben az országokban ugyanis először a termelési és abszorpciós kapacitásokat kellene növelni, megteremteni a szükséges képességeket a technológia felhasználására, mert csak ezeken keresztül valósulhat meg a technológiai fejlesztési tevékenységek kialakulása és így az átállás egy magasabb szintủ innovativitásra. Az innovációs rendszerek fókuszát tehát a tudás terjedésének és átvételének erősítésére kellene helyezni a tudás elöállítása helyett. Eder (2018) négy kulcsfontosságú elemet határoz meg, melyek szükségesek a periférikus országok innovativitásához. Az egyik ilyen elemként a vállalatokhoz kapcsolódó tényezők (például: a vállalatok abszorpciós kapacitása, mérete, stratégiai tervezési képessége) fejlesztését nevezi meg. A szerző szerint alkalmasabb megközelítés a periférikus régiókban elhelyezkedő innovatív vállalatokról beszélni, mintsem innovatív periférikus régiókról. Tsipouri (2018) fontosnak tartja a KKV-k támogatását és az erős vállalkozói ökoszisztéma kialakítását. Emellett hangsúlyozza, hogy az üzleti sikerességhez szükséges az elérhető pénzügyi források sokfélesége, mely sok eset- ben nem adott a vállalatok számára. Pinto és tsai (2013) alapján a KKV-k tudással való ellátásában a tudás-intenzív üzleti szolgáltatásoknak (KIBS) van különösen nagy szerepük a periférikus területeken. Tanulmányukból kiderül, hogy ezek hiányában a regionális vállalatok gyakran használják úgy az egyetemet, mint egyfajta KIBS vállalatot. A szerzők felhívják a figyelmet arra, hogy bár az egyetemek jó helyettesítők lehetnek abban az esetben, ha a régióban nem találhatók KIBS vállalatok, azonban ez negatív hatású is lehet, ugyanis ilyenkor az egyetemek gyengébb minőségủ, de olcsóbb szolgáltatásainak kiszorító hatása lehet a potenciális KIBS vállalatokra. A regionális politikának tehát inkább azt kell támogatnia, hogy a vállalatok hozzáférhessenek a KIBS szolgáltatásokhoz, akár régión kívülről is, és nem az egyetemeket ösztönözni helyettesítő tevékenységre.

A következő tényező, mely a fejletlen régiók innovativitását segíti elő, az a régiók közti hálózatok kialakítása. Mivel a lemaradó régiókban jellemző a kritikus tömeg hiánya, az alacsony szintủ tudásbázis, az innovációs infrastruktúra fejletlensége, a helyi innovatív KKVk a külső kapcsolatokra támaszkodva juthatnak hozzá az új tudáshoz, technológiákhoz (Eder 2018). Ez az új tudás sok esetben inkább kompenzálja a lokális tudás hiányát, gyengeségét, mintsem kiegészítené a meglévő tudásbázist (Grillitsch \& Nilsson 2015). Empirikus vizsgálatok igazolják, hogy a periférián müködő kisvállalatoknak is megvan a lehetőségük a globális piacokon való megjelenésre, van némi abszorpciós kapacitásuk a régión kívüli tudásállomány átvételére, ami nagy szerepet játszik a régió innovativitásának és versenyképességének növelésében (Dubois 2016, Rodríguez-Pose \& Wilkie 2018). A régión átívelő együttmüködések kialakításának egyik megvalósulási módja a formalizált együttmüködési szerződések kötése, illetve a külföldi munkaerő alkalmazása is lehet (Eder 2018). A régión kívülről beérkező vállalkozók pozitív hatással vannak a helyi gazdaságra és innovativitásra, mivel új tudást, ötleteket, képességeket hoznak a régióba, továbbá jellemzően erősebb vállalkozói szellemmel rendelkeznek, és könnyebben alakítanak ki nagy földrajzi távolságokon átívelő partnerkapcsolatokat, mint a helyi szereplők. (Kalantaridis \& Bika 2011) Mindemellett fontos a vállalkozók szociális tőkéjének, kapcsolati hálójának fejlesztése, amihez elengedhetetlen a nagyfokú bizalom kiépítése a szereplök között (Dubois 2016). Reidolf (2016) alapján szükséges, hogy a helyi politika segítse a KKV-kat az ismeretlen partnerekkel való kapcsolatok kialakításában, mert ez sokszor okozhat nehézséget a szereplők számára. Továbbá a helyi 
politikának támogatnia kell a KKV-kat a kapcsolati palettájuk szélesítésében, például a tudományos partnerkapcsolatok kialakításával, mivel elemzése során azt találta, hogy a szereplők változatos kapcsolati hálója pozitív hatással van az innovativitásukra. Rodríguez-Pose és Fitjar (2013) hangsúlyozzák, hogy az úgynevezett 'pipeline' típusú intézkedések (régiók közti kapcsolatok kialakítása, erősítése) lényegesen nagyobb hatást fejthetnek ki a régió fejlődésére, mint a hagyományos 'buzz' típusú beavatkozások (agglomerációk, lokális innovációs rendszer kialakítása). A szerzők azonban felhívják a figyelmet, hogy az elöbbinek hátrányai is vannak, például, hogy nehezen alkalmazható, költséges, nehéz megállapítani, hogy melyik céget, ágazatot támogassák, és milyen nemzetközi partnereket célozzanak meg. Sikeres alkalmazás esetén viszont elősegíti a rögzült sémákból való kitörést.

Eder (2018) alapján a következő meghatározó tényező a jól megválasztott innovációs politika, mely a periférikus régiókban kiemelkedő fontosságú. Az innovációs politika reputációja ezekben a térségekben nem túl kedvezö, ami annak köszönhető, hogy gyakran alkalmaztak más régiók példájáról lemásolt politikákat, melyek nem illeszkedtek a helyi feltételekhez, továbbá az egymással ellentmondó helyi politikák is gyakran megfigyelhetők voltak. Crowley és McCann (2017) megállapítják, hogy a politikai beavatkozásoknak specifikusnak kell lenniük a különbözö ágazati, innovációs, illetve gazdasági típusoknak megfelelően, mivel adott beavatkozások eltérő hatást érhetnek el a különböző típusok esetében. Ennek megfelelően az úgy nevezett 'onesizefitsall', azaz a 'minden típushoz illő' megközelítések nem alkalmasak az innovativitás növelésére. Rodríguez-Pose és Wilkie (2017) szintén arra hívja fel a figyelmet, hogy a jó innovációs politikának figyelembe kell vennie a területi különbségeket, többdimenziósnak, átfogónak kell lennie, továbbá illeszkednie kell a régió korlátjaihoz. Tsipouri (2018) hangsúlyozza az intézményi környezet fejlesztésének fontosságát a fejletlen régiók esetében. A szerző szerint, amennyiben az állami beruházások mértéke meghalad egy kritikus szintet, a kormányzat minőségének fejlesztése fontosabbá válik, mint a fejlesztési kiadások további növelése (Tsipouri 2018). Radosevic (2018) bemutatja, hogy vannak alternatív nézetek, melyek azt szorgalmazzák, hogy a fejletlen régiók ne a gyenge intézményi kapacitásukat próbálják erősíteni, azért, hogy a fejlett régiókban alkalmazott, jól bevált politikai eszközöket ('the best practice') alkalmazni tudják, hanem ehelyett inkább tekintsék adottnak a meglévő kormányzati és intézményi kapacitásaikat, és válasszanak annak megfelelő politikai eszkö- zöket, stratégiákat ('the best matches'). A szerzö rávilágít, hogy mindkét esetben elengedhetetlen a regionális intézményi kapacitások külső felmérése, értékelése.

További sikerességi faktorként nevezi meg az egyetemek jelenlétét Eder (2018). A periférikus régiók, melyek rendelkeznek egyetemi szférával, előnyt élveznek azokkal szemben, ahol nincsenek felsőoktatási intézmények. A szerző azonban hangsúlyozza, hogy ez az előny csak akkor hasznosítható, hogyha az egyetemek erősségei összhangban állnak a régió és a vállalatok igényeivel. Kolehmainen és tsai (2016) alapján az egyetemek a fiatalok és általában a munkaerő megtartásában is fontos szerepet játszanak. Erre jó példa a skót-Highlands and Islands régió, ahol az egyetem megalapítása javított a KKV-k és a $\mathrm{K}+\mathrm{F}$ tevékenységek limitált humánerőforrással való ellátottságának problémáján, továbbá számos munkahelyet teremtett, és jelentős mértékben növelte a régió gazdasági teljesítményét (Kolehmainen et al. 2016). A finn South Ostrobothnia régió lemaradását is az egyetem fejlesztésével sikerült csökkenteni (Sotarauta \& Kosonen 2004). Ennek érdekében jelentős mértékben fejlesztették a régió intézményi bázisát és humánerőforrását, illetve megerősítették a helyi kutatásokat mind mennyiségi, mind minőségi szempontból. A program eredményeképpen sikerült létrehozni egy vonzó multidiszciplináris kutatói milieu-t, melynek révén a helyi vállalatok is bevonódtak a tudásról, innovációról és az új technológiák bevezetéséről szóló vitába (Sotarauta \& Kosonen 2004). Az egyetem-vezérelt innováció a periférikus városi területfejlesztésben is jelentős szerepet kaphat (Addie et al. 2018). Nápolyban létrehoztak egy új egyetemi csomópontot a város elmaradottsággal küzdő részén, mely hozzájárult a térség innovációs rendszerbe való integrálásához. Emellett a helyi KKVkal és az Apple-el kötött együttmüködések révén új képzési programokat hoztak létre, melyek hozzájárulnak a képzett munkaerő megtartásához és a fennálló gazdasági, szociális egyensúlytalanságok csökkentéséhez (Addie et al. 2018).

Brown (2016) elemzése alapján azt állapítja meg, hogy az egyetemek szerepe sok esetben túl van hangsúlyozva a regionális fejlesztések során. Az egyetemek 'harmadik missziója', azaz a gazdasági fejlődés elérése érdekében vállalt szerepe alapján a politikai fókusz nagymértékben az egyetemekre került, amitől az üzleti szféra kutatási inaktivitásának ellensúlyozását várják. Ennek érdekében jelentös pénzügyi források kerültek az egyetemekhez. A szerző szerint azonban ennek a magas ráfordításnak alacsony a megtérülése, továbbá a programok nem hatékonyak. További problémát 
jelent, hogy a kutató egyetemek globális orientáltsága nem találkozik a helyi kisvállalatok szükségleteivel. Az egyetemek gyakran specializálódnak olyan kutatási területekre, melyekhez hiányoznak a kapcsolódó helyi iparágak. A probléma feloldására a szerző a regionális innovációs rendszer többi szereplőjének erősítését, kompetenciáinak fejlesztését javasolja. Kolehmainen és tsai (2016) szintén fontosnak tartják az innovációs rendszer különbözö szereplőinek együttmüködését. A szerző szerint a fejletlen régiók tudásalapú fejlődésének eléréséhez a 'triple helix' modell (kormányzat; ipar; egyetem) helyett a 'quadruple helix' modell ('triple helix' + média és kultúra alapú közösségi tér és civil szféra) alkalmazása különösen előnyös lehet. Utóbbi megvalósítására jó példa az észak-alföldi régió (Kolehmainen et al. 2016).

Isaksen és Trippl (2016) tanulmányukban hangsúlyozzák az exogén tényezők és a politikai beavatkozások szerepét a periférikus régiók új fejlődési pályára való átállása során. A szerzők különbséget tesznek az analitikus és a szintetikus átállási út között. Előbbi az analitikus tudásbázis kialakításán, az egyetemek és kutatóintézetek, továbbá az analitikus tudást hasznosító vállalatok megjelenésén alapszik. Utóbbira pedig jellemző a szintetikus tudásbázis, illetve az azt hasznosító vállalatok, iparágak megjelenése. Mühlviertel és Arendal-Grimstad régiók fejlődését vizsgálva a szerzők azt találták, hogy fontos volt az az exogén hatás, melyet az új, meghatározó szereplők váltottak ki, illetve az általuk megvalósuló vonzó hatás, mely további szereplők megjelenését generálta. Mindemellett elhanyagolhatatlan tényező volt a kormányzat támogató szerepvállalása is (Isaksen \& Trippl 2016). Calignano és tsai (2018) bemutatják, hogy a klaszteresedést indirekt módon támogató politikai kezdeményezés, pontosabban egy klaszter szervezet létrehozása hogyan járulhat hozzá a tudásáramlás hálózatának fejlődéséhez egy lemaradó régióban. Tanulmányukban Apulia körzet esetét vizsgálják, ahol egy klaszter szervezet létrehozásával képesek voltak új tudást hozni a meglévő hálózatba, illetve erősíteni a helyi kapcsolatok kiépülését, összefonódását. A szerzők azonban felhívják a figyelmet arra, hogy a klaszter szervezet túl erős központi szerepe sebezhetővé teszi a hálózatot, különös tekintettel a regionális politika változásaival szemben. A klaszterszervezet létrehozása tehát hasznos eszköz lehet, azonban idejében gondoskodni kell a háttérbe vonulás stratégiájáról, hogy a klaszter önfenntartóvá válhasson (Calignano et al. 2018).

\section{BEFEJEZÉS}

\section{CONCLUSION}

A tudásalapú fejlődés elérése különösen fontos célként jelenik meg a kevésbé fejlett régiók esetében, mivel ezáltal tudják csökkenteni, vagy legalábbis megállítani a lemaradásukat a fejlett régiókkal szemben (RodríguezPose \& Fitjar 2013). A megfelelő fejlesztéspolitika kialakítása során elengedhetetlen azoknak a speciális tényezőknek a számbavétele, melyek akadályozzák ezekben a régiókban a tudásalapú felzárkózást. Emellett érdemes figyelembe venni azokat a fejlesztési javaslatokat is, melyek kifejezetten a lemaradó régiók problémáira kívánnak megoldást nyújtani. A szakirodalomból egyértelmüen kirajzolódik, hogy a fejletlen régióknak a saját kapacitásaikhoz és lehetőségeikhez kell igazítaniuk a politikájukat ahelyett, hogy a fejlett régiókban müködő gyakorlatokat próbálnák megvalósítani egy teljesen más regionális környezetben. 


\section{HIVATKOZÁSOK REFERENCES}

Addie, J-P. D., Angrisani, M. and Falco, S. D. (2018), "University-led innovation in and for peripheral urban areas: new approaches in Naples, Italy and Newark, NJ, US.", European Planning Studies, 26(6), 1181-1201, DOI: 10.1080/09654313.2018.1459505

Brown, R. (2016), "Mission impossible? Entrepreneurial universities and peripheral regional innovation systems", Industry and Innovation, 23(2), 189-205, DOI: 10.1080/13662716.2016.1145575

Calignano, G., Fitjar, R. D. and Kogler, D. F. (2018), "The core in the periphery? The cluster organization as the central node in the Apulian aerospace district”, Regional Studies, 52(11), 14901501, DOI: 10.1080/00343404.2017.1420155

Crowley, F. and McCann, P. (2017), "Firm innovation and productivity in Europe: evidence from innovation-driven and transition-driven economies", Applied Economics, 50(11), 1203-1221, DOI: $10.1080 / 00036846.2017 .1355543$

Dubois, A. (2016), "Transnationalising entrepreneurship in a peripheral region - The translocal embeddedness paradigm", Journal of Rural Studies, 46, 1-11, DOI:10.1016/j.jrurstud.2016.05.003.

Dyker, D. A. and Radosevic, S. (2000), "Building the Knowledge-Based Economy in Countries in Transition - from Concepts to Policies", The Journal of Interdisciplinary Economics, 12(1), 41-70. DOI:10.1177/02601079x00001200103

Eder, J. (2018), "Innovation in the Periphery: A Critical Survey and Research Agenda", International Regional Science Review, 42(2), 119146, DOI: $10.1177 / 0160017618764279$

European Commission (2017), "Competitiveness in low-income and low-growth regions. The lagging regions report", European Commission, 2017.04.10. SWD(2017) 132 final, Brüsszel

European Commission (2020), "Catching up regions", letöltve: https://ec.europa.eu/ regional_policy/en/policy/how/improving-investment/lagging_regions/ 2020.01.10.

Foray, D. (2019), "In Response to 'Six Critical Questions About Smart Spezialisation", European Planning Studies, 27(10), 2066-2078, DOI:10.1080/09654313.2019.1664037

Foray, D., Goddard, J., Beldarrain, X. G., Landabaso, M., McCann, P., Morgan, K., Nauwelaers, C. and Ortega-Argilés, R. (2012), Guide to Research and Innovation Strategies for Smart
Specialisation (RIS3), Luxembourg: Publications Office of the European Union

Grillitsch, M. and Nilsson, M. (2015), "Innovation in peripheral regions: Do collaborations compensate for a lack of local knowledge spillovers?", The Annals of Regional Science, 54(1), 299-321, DOI 10.1007/s00168-014-0655-8

Isaksen, A. and Trippl, M. (2016), "Exogenously Led and Policy-Supported New Path Development in Peripheral Regions: Analytical and Synthetic Routes", Economic Geography, 93(5), 436-457, DOI: 10.1080/00130095.2016.1154443

Kalantaridis, C. and Bika, Z. (2011), "Entrepreneurial origin and the configuration of innovation in rural areas: the case of Cumbria, North West England", Environment and Planning A, 43(4), 866-884, DOI:10.1068/a43341

Karbowski, A. (2017), "Institutional underpinnings of the development of knowledge subsystems in Central and Eastern Europe", Ekonomista, 1, $30-46$

Kokko, A., Tingvall, P. G. and Videnord, J. (2015), "The Growth Effects of R\&D Spending in the EU: A Meta-Analysis", Economics: The Open-Access, Open-Assessment E-Journal, DOI:10.5018/economics-ejournal.ja.2015-40

Kolehmainen, J., Irvine, J., Stewart, L., Karacsonyi Z., Szabó T., Alarinta, J. and Norberg, A. (2016), "Quadruple Helix, Innovation and the Knowledge-Based Development: Lessons from Remote, Rural and Less-Favoured Regions", Journal of the Knowledge Economy, 7(1), 23-42 DOI: 10.1007/s13132-015-0289-9

Kravtsova, V. - Radosevic, S. (2012), "Are systems of innovation in Eastern Europe efficient?", Economic Systems, 36(1), 109-126, doi:10.1016/j.ecosys.2011.04.005.

Papava, V. (2018), "Catching Up and Catch-Up Effect: Economic Growth in Post-Communist Europe (Lessons from the European Union and the Eastern Partnership States)", European Journal of Economic Studies, 7(2), 109-125, DOI:10.13187/es.2018.7.109.

Pinto, H., Fernandez-Esquinas, M. and Uyarra, E. (2013), "Universities and Knowledge-Intensive Business Services (KIBS) as Sources of Knowledge for Innovative Firms in Peripheral Regions", Regional Studies, 49(11), 1873-1891, DOI: $10.1080 / 00343404.2013 .857396$

Polónyi I. (2018), “A magyar innováció nemzetközi összehasonlításban”, Educatio, 27(2), 161-176, DOI: $10.1556 / 2063.27 .2018 .2 .1$

Radosevic, S. (2018), "Fostering innovation in less-developed and low institutional capacity regions: Challenges and opportunities", Back- 
ground paper for an OECD/EC Workshop on 22 June 2018 within the workshop series "Broadening innovation policy: New insights for regions and cities", Paris.

Reidolf, M. (2016), "Knowledge networks and the nature of knowledge relationships of innovative rural SMEs", European Journal of Innovation Management, 19(3), 317336, DOI:10.1108/ ejim-06-2015-0043

Rodríguez-Pose, A. and Fitjar, R. D. (2013), "Buzz, Archipelago Economies and the Future of Intermediate and Peripheral Areas in a Spiky World", European Planning Studies, 21(3), 355-372, DOI: $10.1080 / 09654313.2012 .71$

Rodríguez-Pose, A. and Wilkie, C. (2017), "Innovation and competitiveness in the periphery of Europe", Huggins, R. and Thompson, P. (Eds.): Handbook of Regions and Competitiveness Contemporary Theories and Perspectives on Economic Development, Cheltenham: Edward Elgar Publishing, 351-380

Rodríguez-Pose, A. and Wilkie, C. (2018), "Innovating in Less Developed Regions: What Drives Patenting in the Lagging Regions of Europe and North America", Growth and Change, 50(1), 4-37, DOI:10.1111/grow. 12280

Shearmur, R. (2015), "Far from the Madding Crowd: Slow Innovators, Information Value, and the Geography of Innovation" Growth and Change, 46(3), 424-442, DOI:10.1111/ grow. 12097

Shearmur, R. and Doloreux, D. (2016), "How open innovation processes vary between urban and remote environments: slow innovators, market-sourced information and frequency of interaction", Entrepreneurship \& Regional Development, 28(5-6), 337-357, DOI: 10.1080/0898562 6.2016 .1154984

Sotarauta, M. and Kosonen, K-J. (2004), "Strategic adaptation to the knowledge economy in less favoured regions: A South Ostrobothnian university network as a case in point", Cooke, $\mathrm{P}$. and Piccaluga, A. (Eds.): Regional Economies as Knowledge Laboratories, Cheltenham: Edward Elgar, DOI:10.4337/9781845423391.00008

Tsipouri, L. (2018), Fostering innovation in less-developed and low institutional capacity regions: Challenges and opportunities, Background paper for an OECD/EC Workshop on 22 June 2018 within the workshop series "Broadening innovation policy: New insights for regions and cities", Paris.
Veugelers, R. (2011), “Assessing the potential for knowledge-based development in the transition countries of Central and Eastern Europe, the Caucasus and Central Asia", Society and Economy, 33(3), 475-504, DOI: 10.1556/ SocEc.33.2011.3.3

Veugelers, R. and Mrak, M. (2009), The knowledge economy and catching-up member states of the European Union. Report prepared for Commissioner's Potočnik's Expert Group “Knowledge for Growth" 
Polónyi-Andor Krisztina, tudományos segédmunkatárs andor.krisztina@ktk.pte.hu

Pécsi Tudományegyetem

Közgazdaságtudományi Kar

MTA-PTE Innováció és Gazdasági Növekedés Kutatócsoport Regionális Innováció- és Vállalkozáskutató Központ (RIERC)

\section{Possibilities of knowledge-based development in the lagging regions of the $\mathbf{E U}$}

\section{THE AIMS OF THE PAPER}

Nowadays, the knowledge-based development as a goal is getting more emphatic inside the European Union. The growth of innovation and so the productivity is important not only for the developed regions but for regions lagging behind. However, the practical experiences show that the lagging regions have to face many challenges in this field. The aim of the paper is to show the hindering factors and also the supportive recommendations in relation to the catching up process of the underdeveloped regions.

\section{METHODOLOGY}

The methodology used in the paper is literature review. The factors which hinder the knowledge-based development in the lagging regions and also the developmental suggestions given for them are collected from the scientific literature.

\section{MOST IMPORTANT RESULTS}

Based on the literature, the barriers of the knowledge-based catch up can be defined as the lack of skilled human capital, weak entrepreneurship, insufficient institutional environment, risk of lock-in, low return of R\&D expenditures and in many cases the history of the region. Many suggestions have been formed in order to solve these problems, e.g. the development of absorption capacities, formation of a strong entrepreneurial ecosystem, the improvement of the institutional environment, the implementation of a place-based innovation policy and the development of the skills of all actors of the regional innovation system.

\section{RECOMMENDATIONS}

Despite their significant deficiencies, also the lagging regions should seek to reach the knowledge-based development. Since they face specific challenges, it is not sufficient to imitate the good practices of developed regions, but they should adjust their regional policy to their available capacities.

Keywords: lagging regions, knowledge-based development, regional policy

Acknowledgements: This publication/research has been supported by the European Union and Hungary and co-financed by the European Social Fund through the project EFOP-3.6.2-16-2017-00017, titled ,Sustainable, intelligent and inclusive regional and city models". 